\title{
The Potential of Gedongsongo Temple Ornaments In Ornament Design Learning
}

\author{
Syafii $^{1} \&$ Triyanto $^{2}$ \\ \{syafii@mail.unnes.ac.id', triyanto@mail.unnes.ac.id's\} \\ ${ }^{1,2}$ Department of Fine Arts, Faculty of Language and Art, Universitas Negeri Semarang
}

\begin{abstract}
The potential of local art around the Universitas Negeri Semarang campus is very abundant, but has not been utilized in learning. In this regard, through this research, it was developed in lectures as a cultural conservation in the subject of Ornament Design. The research objectives were to find the potential of Gedongsongo temple ornaments and explain the perceptions of UNNES Department of Fine Arts students in response to learning Ornament Design by utilizing the potential of local art of Gedongsongo temple ornaments. The research chosen was qualitative and quantitative approach. The results showed that Gedongsongo temple ornaments had a number of potentials in the context of learning, namely the potential of creative learning with the content of aesthetic experiences. Student perceptions in the Ornament Design learning by utilizing averaged in the range agree and strongly agree that in their opinion learning is easier, more enjoyable and does not limit creativity.
\end{abstract}

Keywords: potential of local art, ornaments, designs, temples

\section{Introduction}

Determination of local art subjects as a local content curriculum of the Univeritas Negeri Semarang (UNNES) Department of Fine Arts has not been developed through research, so it has not yet described the students needs. The Ornament Design Subject is one of the local content subjects designed to accommodate cultural conservation needs as well as a means of developing student creativity on the other side. Cultural conservation needs related to learning ornament design can be done by utilizing the potential of local arts around the campus, one of which is the ornament of Gedongsongo temple. On the other hand, the creativity of students can be accommodated and developed by utilizing the Gedongsongo temple ornaments as a source, or rather, the ornament is used as a stimulus in producing design works as a creative response.

Researches on temple ornaments have been attempted but only limited to identifying the types and shapes of ornaments [1] [2] [3] [4]. Other studies examine the equality and beauty of temple ornaments with temples or other buildings [5][6][7]. The next research is related to the meaning of Hindu and Buddhist temple ornaments in Java [8]. All these studies are not or have not touched on the ornaments of the Gedongsongo temple.

The research related to the Gedongsongo temple was carried out by the author in connection with the development of teaching materials [9] and Gedongsongo temple ornaments as a learning ornament design stimulus [10]. Both of these studies have not examined further the potential and perceptions of students in learning Ornament Design with the use of Gedongsongo temple ornaments.

Thus, through this research, it is expected to obtain empirical information about Gedongsongo temple ornaments as an effort to develop science, especially in the field of art studies in cultural conservation areas. This research can contribute to the potential of local art of Gedongsongo temple ornaments which can be appointed as a source of learning for subjects at the FBS UNNES Department of Fine Arts, especially in Ornament Design subjects.

Starting from this, the purpose of this study was to find the potential of Gedongsongo temple ornaments and explain the perceptions of UNNES Department of Fine Arts students in response to learning Ornament Design by utilizing the potential of local art of Gedongsongo temple ornaments. 


\section{Methods}

This study used a qualitative and quantitative approach. The qualitative approach was used to answer the potential problems of Gedongsongo temple ornaments in the context of learning. While the quantitative approach to addressing problems was perceived as a response to the students of the UNNES Department of Fine Arts in learning Ornament Design using Gedongsongo temple ornaments.

The data collection techniques of this research were observation and questionnaire. Observation was used to examine the potential symptoms relating to Gedongsongo temple ornaments for the sake of learning subject of Ornament Design. Therefore observations were directed to explore information relating to the diversity of geometric, plant, animal, human, and other motives. Meanwhile, questionnaires were used to explore students' persepsional data on learning Ornament Design. A sample of 40 people was obtained accidentally when students attended the final lecture of the Ornament Design course.

In accordance with the chosen approach, the data analysis technique used was descriptive, both qualitative and quantitative. Qualitative analysis was in order to find the embodiment of potential Gedongsongo temple ornaments as a source of learning. The procedure performed follows the line of thought of Spradley with the first step being analyzing domains, taxonomics, and componential[11][12]. In particular the analysis of the embodiment of the ornament was done with visual content or artistic analysis. Quantitative descriptive analysis was used to explain perceptions as a form of response from UNNES Department of Fine Arts students in learning Ornament Design by utilizing the potential of local art of Gedongsongo temple ornaments.

\section{Results and Discussion}

\subsection{Research Setting}

Gedongsongo is the name of the temple which is administratively located in Semarang Regency, Central Java Province. The location is in the tourism area of Bandungan. It was named Gedongsongo because it was believed that the number of buildings in the complex was nine or sanga, although when this research was conducted, it was only known that the temple complex was 1 to 5 .

There are a number of ornaments with geometric, plant, animal and human motifs that can be found in the temple complex. In its realization, there are similarities with other temple ornaments, for example in the depiction of motifs of kala makara, sticky notes, and tendrils. Although there are similarities with other temples, the Gedongsongo temple ornaments are very relevant as a source of learning taking into account the proximity of the location.

Subjects at the Department of Fine Arts UNNES which are directly related to ornaments are Ornament Designs. Through this subject students are expected to have competence in producing ornament designs, especially wallpaper, batik, and carving designs.

\subsection{Gedongsongo Ornament Potential in the Context of Ornament Design Learning}

Gedongsongo Temple, based on observations, still holds a number of ornaments including geometric, plant, animal and human motifs. This is in line with the contents of the Ornament Design subject at the UNNES Department of Fine Arts. Thus it can be affirmed that the ornaments of Gedongsongo temple have the potential to be used in the learning of Ornament Design.

Departing from this, the researchers conducted controlled observations by utilizing Gedongsongo temple ornaments when students explored the creation of various motives and their application in wallpaper design, batik and carving. Various designs which were produced by students as presented in Figures 1 and 2.

The potential that can be directly developed for students is creative competence, the ability to produce ornamental design works based on local potential. Although among the students argued that it limits creativity, Gedongsongo temple ornaments in Ornament Design learning can be used as a reference, a source of inspiration/ideas when they work. 


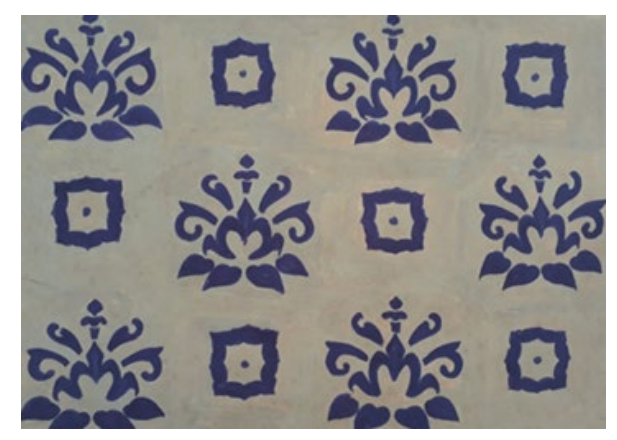

Fig. 1.Wallpaper DesignWidya Maya's work

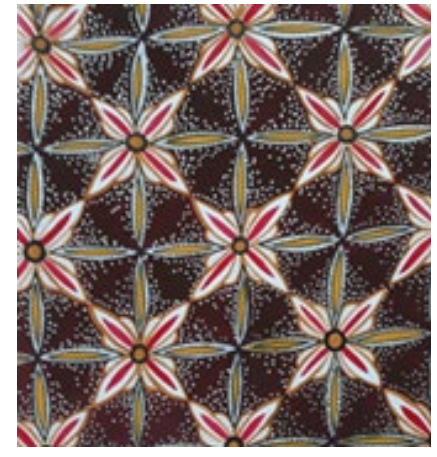

Fig. 2.Batik Design Oktafia Indah's work

A number of aesthetic experiences were also obtained during learning. The aesthetic experience is related to fulfilling the institution's vision, namely cultural conservation, $90 \%$ of students agree. Based on the questionnaire also showed that $100 \%$ of students felt that learning could provide an experience to be proud of past artworks, and $82.5 \%$ of students felt concerned about the environment.

\subsection{Student Perception in Ornament Design Learning}

Based on questionnaire contents, related to the ease of making designs, learning situations, developing creativity, the diversity of aesthetic experiences gained, and the spirit of learning art based on local potential through descriptive analysis are presented in table 1 as follows.

Table 1. Student Perceptions in Learning

\begin{tabular}{|c|c|c|c|}
\hline Indicator of Perception & $\mathrm{N}$ & Mean & $\begin{array}{c}\text { Std. } \\
\text { Deviation }\end{array}$ \\
\hline Facilitate Making Designs & 40 & 3.12 & .607 \\
\hline Fun in the Learning Process & 40 & 3.05 & .504 \\
\hline Limiting Creativity in Developing Design & 40 & 2.85 & .700 \\
\hline Provides a diversity of aesthetic experiences & 40 & 3.47 & .554 \\
\hline $\begin{array}{l}\text { Encouraging the Spirit of Learning Art Based } \\
\text { on Local Potential }\end{array}$ & 40 & 3.46 & .555 \\
\hline
\end{tabular}

The data analysis showed that the Ornament Design Learning by utilizing Gedongsongo temple ornaments as a source of learning was positively perceived by students, this was shown to be the lowest average of 2.85 in the development of creativity and the highest 3.47 in providing a diversity of artistic experiences. In learning, especially when students design wallpaper, batik, and carvings, they are given the stimulus of Gedongsongo temple ornaments, therefore, it can be understood if students in developing their creativity feel limited. However, students' perceptions that learning limited creativity only showed $27 \%$, the rest they held the opposite view.

Thus it can be affirmed that the perceptions of UNNES Department of Fine Arts students in learning Ornament Design by utilizing Gedongsongo temple ornaments as a source of learning are positive. Therefore, learning with these models should be recommended. 


\section{Conclusion}

Based on the results of the study, the Gedongsongo temple ornament has a number of potentials in the learning context of Ornament Design, namely the potential of creative learning with a charge of aesthetic experience. The potential of creative learning, Gedongsongo temple ornaments can be used as a reference, a source of inspiration/ ideas when students in designing designs, especially the design of wallpaper, batik and carving, as well as the scope of lecture content. Aesthetic experiences in the context of learning is related to the vision of cultural conservation, pride in the art of the past, and concern for the environment. Student perceptions in the Ornament Design learning by utilizing the potential of Gedongsongo temple ornaments show a positive scale in the range agree and strongly agree. This, according to their opinions, learning is easier, more enjoyable and does not limit creativity.

\section{References}

[1] Supatmo, et al., Motif dan Pola Ornamen Candi Kalasan Yogyakarta, The Research Report is not Published, FBS UNNES, 2008.

[2] Supatmo, et al, Ornamen Kala pada Candi Prambanan dan Sewu, The Research Report is not Published, FBS UNNES, 2009.

[3] Supatmo, et al., Bentuk Ornamen Kala Makara pada Kompleks Candi Plaosan Jawa Tengah, The Research Report is not Published, FBS UNNES, 2010.

[4] Sunaryo, A. et al, Bentuk dan Pola Ornamen Candi-candi Budha di Jawa Tengah, The Research Report is not Published, FBS UNNES, 2008.

[5] Basudewa, D.G.Y. and Titasari, C.P. "Kesetaraan Ornamen Kala-Makara dengan Karang Bhoma: Studi Kasus di Pura Dalem Desa Taman Pohmanis". Forum Arkeologi, vol 28, no 3, November 2015, pp.177-186.

[6] Arifin, F. 2015. "Representasi Simbol Candi Hindu dalam Kehidupan Manusia: Kajian Linguistik Antropologis". Penelitian Humaniora, vol 16, no 2, Agustus 2015, pp. 12-20.

[7] Wardani, L.K., Sitinjak, R.H., and Sari, S.M.,"Estetika Ragam Hias Candi Bentar dan Paduraksa di Jawa Timur”.Konferensi Nasional Pengkajian Seni, Arts and Beyond, 2016.

[8] Halim, A. and Herwinto, R.P. 2017. "Makna Ornamen pada Bangunan Candi Hindu dan Budha di Pulau Jawa (Era Klasik Tua-Klasik Tengah-Klasik Muda)". Journal of Risa, vol 01, no 2, April 2017, pp.170-191.

[9] Syafii, "Pengembangan Bahan Ajar Ornamen Berbasis Candi di Jawa Tengah: Studi Identifikasi Candi Gedongsongo". Imajinasi, vol 11, no 2, Juli 2017, pp. 117-124.

[10] Syafii, "Ornamen Design by Student of Fine Art Education in Semarang State University as Creative Response to the Ornament of Gedongsongo Temple". Imajinasi, vol 12, no 2, pp. 21-28.

[11] Spradley, J.P., The Ethnographic Interview, New York: Holt, Rinehart and Winston,1979.

[12] Spradley,J.P., Participant Observation, New York: Holt, Rinehart and Winston, 1980. 